\title{
ČELIČNI PLOŠNI ELEMENTI OPTEREĆENI U SVOJOJ RAVNINI: FAKTORI IZBOČIVANJA
}

\author{
Mladen Bulić \\ Građevinski fakultet Rijeka Sveučilišta u Rijeci, doc.dr.sc. \\ Mehmed Čaušević \\ Građevinski fakultet Rijeka Sveučilišta u Rijeci, prof.dr.sc.
}

Sažetak: Cilj rada je pokazati kako su nastale vrijednosti faktora izbočivanja koje su dane kao gotove brojčane vrijednosti u postojećoj literaturi iz čeličnih konstrukcija i u europskim normama za čelične konstrukcije. U radu je obrađena stabilnost čeličnih plošnih elemenata opterećenih u svojoj ravnini na način kako se ovaj problem rješava u mehanici. Dana je opća teorija stabilnosti plošnih nosača te je izvedena jednadžba izbočivanja plošnog elementa. Objašnjen je pojam elastičnog kritičnog naprezanja izbočivanja ploče $\sigma_{c r}$ te s njim u vezi i faktor izbočivanja ploče $k_{\sigma}$ za proizvoljne rubne uvjete, raspodjelu naprezanja i odnos dužine i širine ploče. Uz to su prikazani dijagrami iz literature pomoću kojih se mogu odrediti približne vrijednosti faktora izbočivanja za razne rubne uvjete i različite odnose dužine i širine ploče. Na kraju je prikazan primjer izračuna faktora izbočivanja i kritičnog naprezanja plošnog elementa, i to i analitički i primjenom specijaliziranog softverskog paketa EBPlate [11] koji je utemeljen na europskoj normi EN 1993-1-5 [3].

Ključne riječi: faktor izbočivanja, stabilnost plošnog elementa, jednadžba izbočivanja ploče, softverski paket EBPlate

\section{STEEL PLATE ELEMENTS LOADED IN THEIR PLANE: BUCKLING FACTORS}

\begin{abstract}
The aim of this paper is to present the way how the values of buckling factor are derived, which are provided as a ready-made numerical values in the existing literature on steel structures and European standards for steel structures. In this paper the stability of steel plate elements loaded in their plane is presented in the way how this problem is solved in mechanics. The general theory of stability of plates is given and the equation of buckling of plate elements is derived. The elastic critical buckling stress for plate $\sigma_{c r}$ is explained as well as the plate buckling factor $k_{\sigma}$ for arbitrary boundary conditions, arbitrary distribution of external loading on the plate and arbitrary relationship between length and width of the plate. In addition the values of buckling factor for various boundary conditions and arbitrary relationship between length and width of the plate are presented using the diagrams in the literature. Finally, an example of a plate element calculated analytically and computed using specialized software package EBPlate [11], which is based on the European standard EN 1993-1-5 [3], is presented.
\end{abstract}

Key words: buckling factor, stability of plated element, equation of plate buckling, software package EBPlate 


\section{Plošni elementi u tlaku}

\subsection{Uvod}

Poprečni presjeci konstrukcijskih elemenata, valjani ili zavareni, mogu se razmatrati kao da su sastavljeni iz plošnih elemenata od kojih su neki unutarnji (npr. hrptovi otvorenih poprečnih presjeka ili pojasnice sandučastih presjeka), a neki su vanjski (npr. pojasnice otvorenih poprečnih presjeka i krakovi kutnika). Budući da su plošni elementi poprečnih presjeka klase 4 relativno tanki u usporedbi s njihovom širinom, kada su tlačno naprezani u svojoj ravnini (kao rezultat uzdužne tlačne sile koja djeluje na cijeli poprečni presjek i/lii od savijanja) mogu se lokalno izbočiti, te se na taj način uzima njihova umanjena vrijednost poprečnog presjeka, tablica 1.1 [1], [6]. Lokalno izbočivanje plošnog elementa, bez obzira na njegov razmještaj u poprečnom presjeku, ograničava otpornost presjeka ili cijelog elementa na uzdužnu silu ili otpornost na savijanje, sprječavajući dosezanje tečenja presjeka. Izbjegavanje preuranjenog otkazivanja nastalog zbog učinaka lokalnog izbočivanja može se postići ograničavajući odnos širine i debljine pojedinog plošnog elementa poprečnog presjeka, te poprečnim i uzdužnim ukrućivanjem.

U nastavku ćemo pokazati kako su nastale vrijednosti faktora izbočivanja $k_{\sigma}$ iz tablice 1.1 , a numerički ćemo obraditi primjer u kojem je dobivena vrijednost $k_{\sigma}=4,0$ iz tablice 1.1. Isti primjer će biti obrađen i analitički te primjenom specijaliziranog softverskog paketa EBPlate [11].

\section{Tablica 1.1 - Određivanje $k_{\sigma}$ za unutarnji element u tlaku}

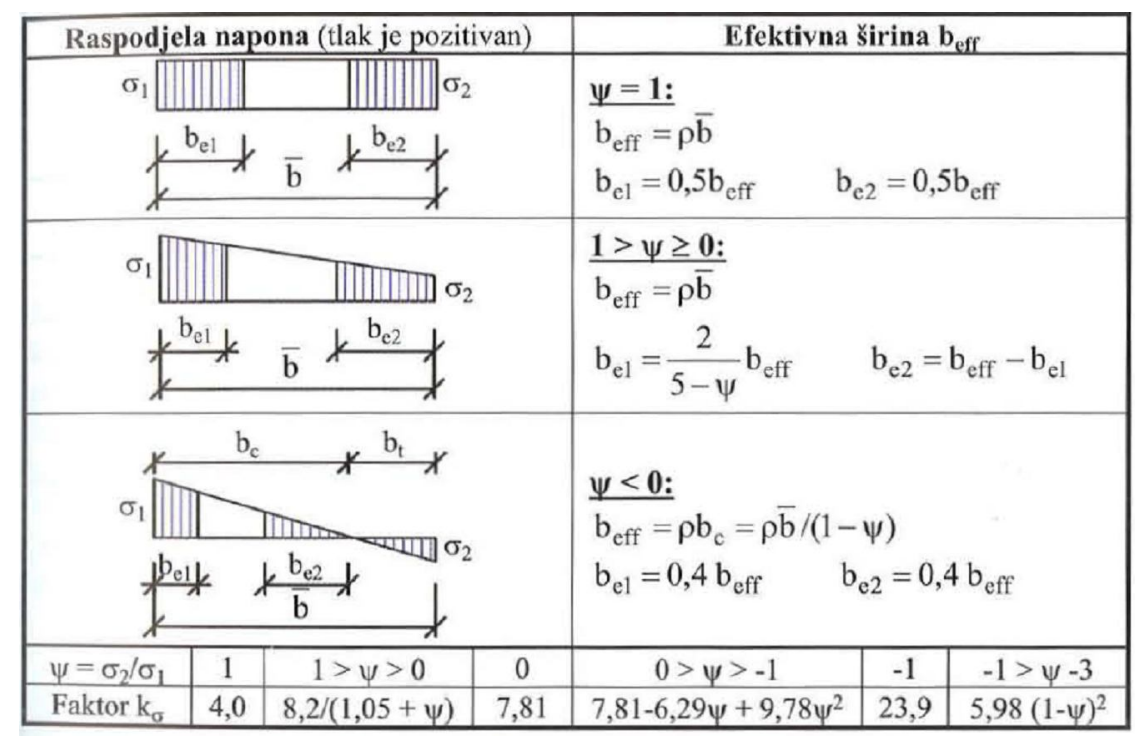

Potreba za poznavanjem teorije stabilnosti plošnih elemenata opterećenih u svojoj ravnini, osim za razumijevanje načina definiranja klase 4 poprečnog presjeka - redukcije površine poprečnog presjeka klase 4 (određivanje faktora izbočavanja $k_{\sigma}$ ), iskazuje se i u sljedećim slučajevima:

- $\quad$ kod bočno torzijskog izvijanja elemenata (EN 1993-1-1) [2]

- kod stabilnosti tlačno opterećenih čeličnih štapova sastavljenih od plošnih elemenata (hrptova i pojasnica) (EN 1993-1-1) [4], [8]

- u analizi stabilnosti visokih limenih nosača kod mostova (EN 1993-1-5) [3], [7]

- $\quad$ u analizi stabilnosti limenih nosača s ukrućenjima (EN 1993-1-5). 


\subsection{Opća teorija stabilnosti plošnih nosača}

\subsubsection{Naprezanje od savijanja}

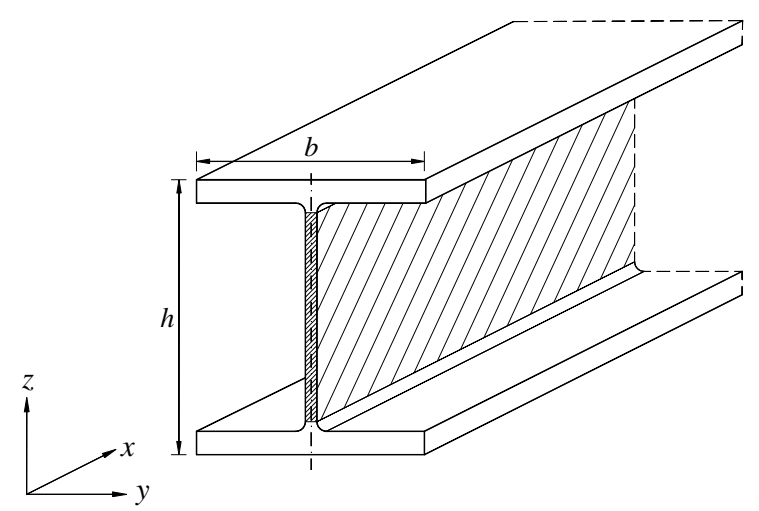

\section{Slika 1.1 - Promatrani dio vitkog čeličnog elementa}

Promatrajmo diferencijalno mali dio hrpta prikazan na slikama 1.2 i 1.3 za koji se (prema općoj teoriji savijanja ploča), iz uvjeta ravnoteže u pravcu okomitom na promatranu ravninu, može formirati diferencijalna jednadžba progiba plošnog elementa [5]:

$$
\begin{aligned}
& q \cdot d x \cdot d z-D\left(\frac{\partial^{4} w}{\partial x^{4}}+2 \frac{\partial^{4} w}{\partial x^{2} \partial z^{2}}+\frac{\partial^{4} w}{\partial z^{4}}\right) d x \cdot d z=0 \\
& q \cdot d x \cdot d z-D \cdot \Delta \Delta w \cdot d x \cdot d z=0 \\
& \Delta \Delta w=\frac{Y}{D}
\end{aligned}
$$

u kojoj je:

$w$ - pomak okomito na ravninu $d x \cdot d z$

$Y$ - opterećenje okomito na ravninu $d x \cdot d z, Y=q \cdot d x \cdot d z$

$D$ - krutost plošnog elementa na savijanje

$$
D=\frac{E h^{3}}{12\left(1-v^{2}\right)}
$$

gdje je

$$
\begin{aligned}
& v \text { - Poissonov koeficijent } \\
& h \text { - debljina plošnog elementa } \\
& E \text { - modul elastičnosti. }
\end{aligned}
$$




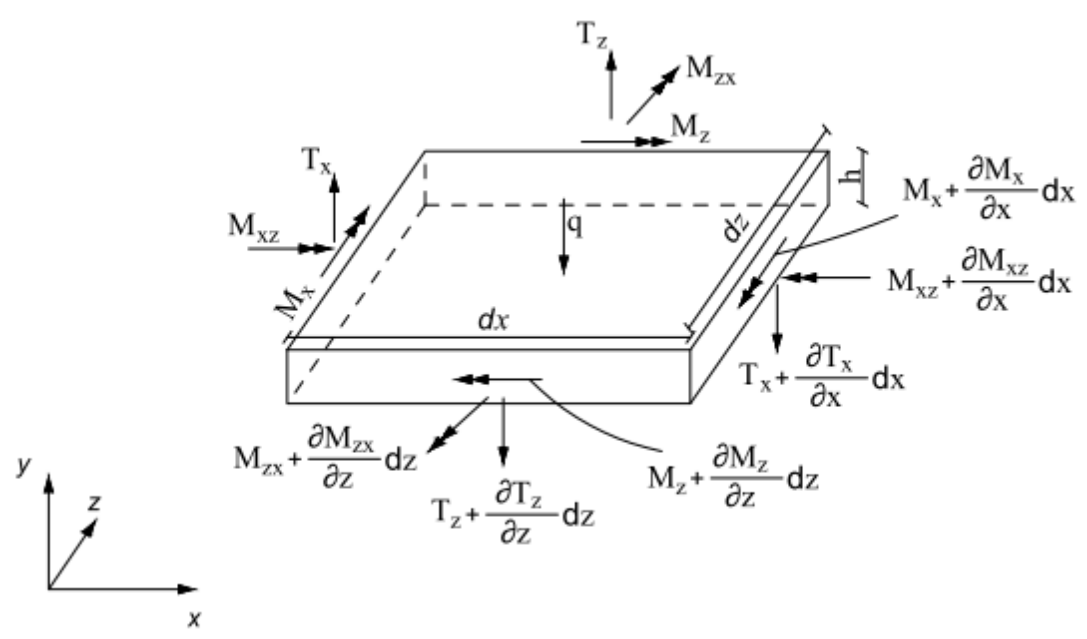

Slika 1.2 - Diferencijalno mali dio hrpta

\subsubsection{Naprezanje u ravnini}

$\mathrm{Na}$ diferencijalno mali element djeluju samo one sile koje se nalaze u srednjoj ravnini elementa, a to su: $N_{x}, N_{z}, T_{x z}=T_{z x}$

Ako promatramo srednju ravninu ploče (slika 1.3), poprečne sile dobivamo integracijom naprezanja po visini presjeka. Ako se pretpostavi da je $d x=d z=1$, one imaju sljedeće vrijednosti:

$$
\begin{aligned}
& N_{x}=\int_{-h / 2}^{h / 2} \sigma_{x} \cdot d y=\sigma_{x} \cdot h \\
& N_{z}=\int_{-h / 2}^{h / 2} \sigma_{z} \cdot d y=\sigma_{z} \cdot h \\
& T_{x z}=T_{z x}=\int_{-h / 2}^{h / 2} \tau_{x z} \cdot d y=\int_{-h / 2}^{h / 2} \tau_{z x} \cdot d y=\tau_{x z} \cdot h
\end{aligned}
$$

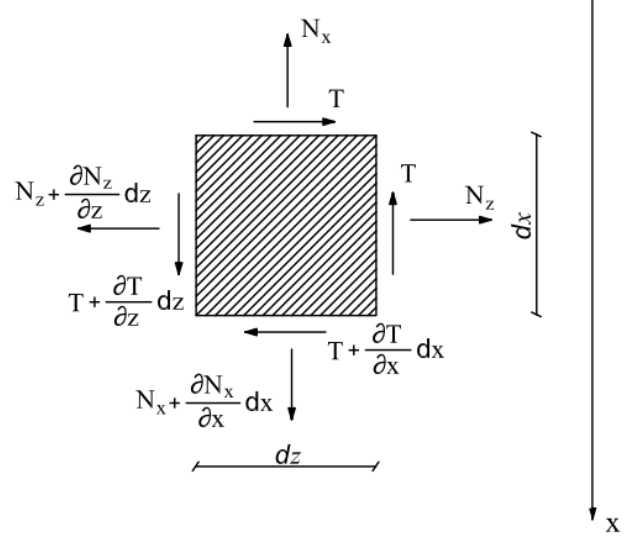

Slika 1.3 - Srednja ravnina ploče 
Utjecaj uzdužnih sila prikazan je na slici 1.4 gdje se, s obzirom da je $\theta_{x}$ mala veličina, može pretpostaviti: $\sin \theta_{z} \cong \operatorname{tg} \theta_{z}=\frac{\partial w}{\partial z} \quad \sin \theta_{x} \cong \operatorname{tg} \theta_{x}=\frac{\partial w}{\partial x}$
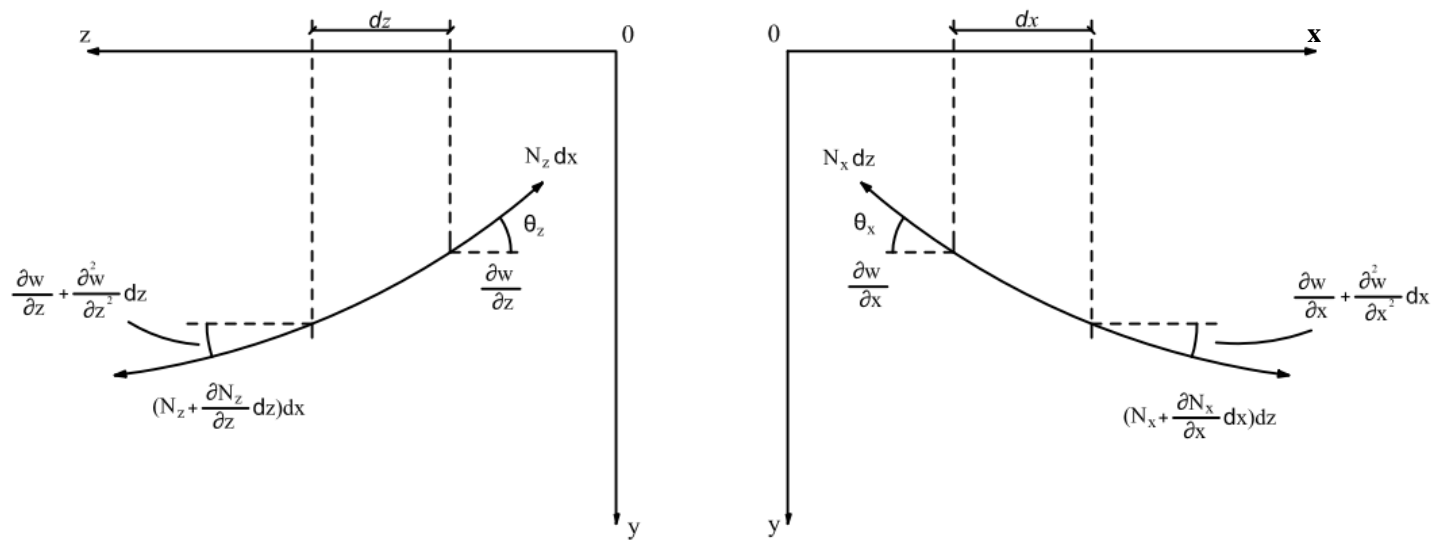

\section{Slika 1.4 - Utjecaj uzdužnih sila}

Tada je suma projekcija uzdužnih sila na y os:

$$
\begin{aligned}
\sum Y_{(N)}= & -N_{x} \frac{\partial w}{\partial x} \cdot d z+\left(N_{x}+\frac{\partial N_{x}}{\partial x} d x\right) d z \cdot\left(\frac{\partial w}{\partial x}+\frac{\partial^{2} w}{\partial x^{2}} d x\right)- \\
& -N_{z} \frac{\partial w}{\partial z} \cdot d x+\left(N_{z}+\frac{\partial N_{z}}{\partial z} d z\right) d x \cdot\left(\frac{\partial w}{\partial z}+\frac{\partial^{2} w}{\partial z^{2}} d z\right)
\end{aligned}
$$

odnosno nakon sređivanja:

$$
\sum Y_{(N)}=\left(\frac{\partial N_{x}}{\partial x} \cdot \frac{\partial w}{\partial x}+\frac{\partial N_{z}}{\partial z} \cdot \frac{\partial w}{\partial z}+N_{x} \frac{\partial^{2} w}{\partial x^{2}}+N_{z} \frac{\partial^{2} w}{\partial z^{2}}\right) d x \cdot d z
$$

Utjecaj poprečnih sila prikazan je na slici 1.5, prema kojoj možemo formirati relaciju:

$$
\begin{aligned}
\sum Y_{(T)}= & -T \frac{\partial w}{\partial x} \cdot d x+\left(T+\frac{\partial T}{\partial z} d z\right) d x \cdot\left(\frac{\partial w}{\partial x}+\frac{\partial^{2} w}{\partial x \cdot \partial z} d z\right)- \\
& -T \frac{\partial w}{\partial z} \cdot d z+\left(T+\frac{\partial T}{\partial x} d x\right) d z \cdot\left(\frac{\partial w}{\partial z}+\frac{\partial^{2} w}{\partial x \cdot \partial z} d x\right)
\end{aligned}
$$

Nakon što se zanemare utjecaji malih veličina višeg reda, ona postaje:

$$
\sum Y_{(T)}=\left(\frac{\partial T}{\partial x} \cdot \frac{\partial w}{\partial z}+\frac{\partial T}{\partial z} \cdot \frac{\partial w}{\partial x}+2 T \frac{\partial^{2} w}{\partial x \partial z}\right) d x \cdot d z
$$




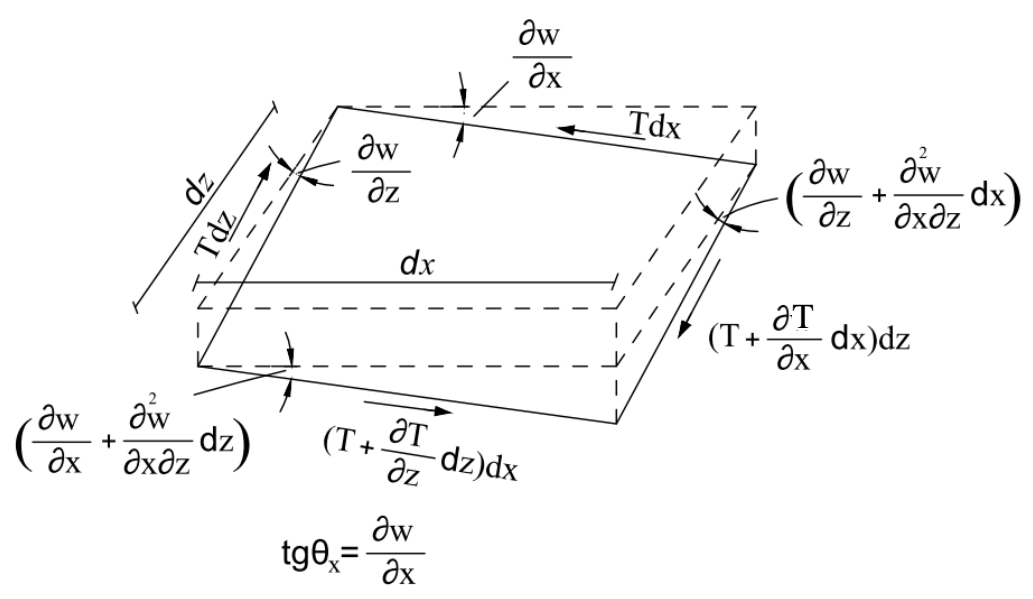

\section{Slika 1.5 - Utjecaj poprečnih sila}

Sada se može napisati uvjet ravnoteže svih sila koje djeluju na diferencijalno mali element (naprezanje na savijanje zbrojeno s naprezanjem u ravnini) u pravcu y osi (zbroj jednadžbi 1, 2 i 3 ):

$$
\begin{aligned}
\sum Y & =\sum Y_{(q)}+\sum Y_{(N)}+\sum Y_{(T)}= \\
& =q \cdot d x \cdot d z-D \cdot \Delta \Delta w \cdot d x \cdot d z+\left(\frac{\partial N_{x}}{\partial x} \cdot \frac{\partial w}{\partial x}+\frac{\partial N_{z}}{\partial z} \cdot \frac{\partial w}{\partial z}+N_{x} \frac{\partial^{2} w}{\partial x^{2}}+N_{y} \frac{\partial^{2} w}{\partial z^{2}}\right) d x d z+ \\
& +\left(\frac{\partial T}{\partial x} \cdot \frac{\partial w}{\partial z}+\frac{\partial T}{\partial z} \cdot \frac{\partial w}{\partial x}+2 T \frac{\partial^{2} w}{\partial x \partial z}\right) d x d z=0
\end{aligned}
$$

Množeći ovaj uvjet s $1 / d x d z$, dobivamo:

$$
q-D \cdot \Delta \Delta w+N_{x} \frac{\partial^{2} w}{\partial x^{2}}+N_{z} \frac{\partial^{2} w}{\partial z^{2}}+2 T \frac{\partial^{2} w}{\partial x \partial z}+\left(\frac{\partial N_{x}}{\partial x}+\frac{\partial T}{\partial z}\right) \frac{\partial w}{\partial x}+\left(\frac{\partial N_{z}}{\partial z}+\frac{\partial T}{\partial x}\right) \frac{\partial w}{\partial z}=0
$$

Članovi posljednje jednadžbe $\left(\frac{\partial N_{x}}{\partial x}+\frac{\partial T}{\partial z}\right) \frac{\partial w}{\partial x}$ i $\left(\frac{\partial N_{z}}{\partial z}+\frac{\partial T}{\partial x}\right) \frac{\partial w}{\partial z} \quad$ su male veličine višeg reda koje se zanemaruju, a zanemaruje se i poprečno opterećenje $q$. Pritom treba imati u vidu i promjenu predznaka uzdužnih sila za slučaj kada su one tlačne. Na kraju se dobiva jednadžba izbočivanja ploče u obliku:

$$
-D \nabla w+\left(N_{x} \frac{\partial^{2} w}{\partial x^{2}}+2 T \frac{\partial^{2} w}{\partial x \partial z}+N_{z} \frac{\partial^{2} w}{\partial z^{2}}\right)=0
$$

Rubni uvjeti za dva osnovna slučaja oslanjanja ploče će biti:

- za zglobno oslonjenu $w=0$ i $w^{\prime \prime}=0$

- za upetu ploču $w=0$ i $\quad w^{\prime}=0$

Dalje ćemo razmotriti najjednostavniji slučaj izbočivanja zglobno oslonjene pravokutne ploče koja predstavlja npr. hrbat I profila i na koju djeluje jednoosno, tlačno ravnomjerno raspoređeno opterećenje, prema shemi na slici 1.6. 


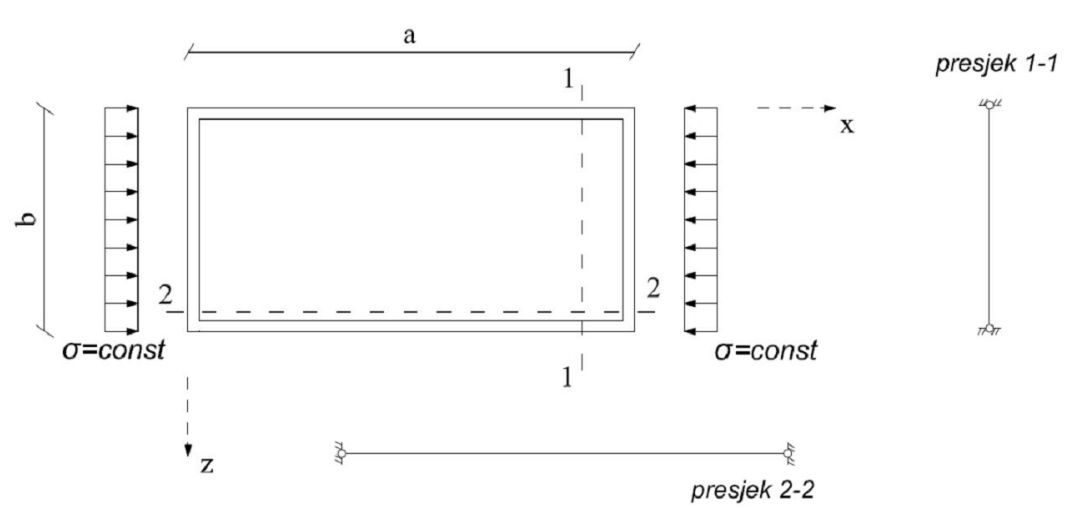

Slika 1.6 - Zglobno oslonjena pravokutna ploča na koju djeluje jednoosno tlačno ravnomjerno raspoređeno opterećenje

Kako je $N_{x}=\sigma \cdot h, N_{z}=0$ i $T=0$ jednadžba (4) se svodi na:

$$
D \nabla w+\sigma \cdot h \frac{\partial^{2} w}{\partial x^{2}}=0
$$

Rješenje ove jednadžbe tražimo u obliku dvostrukog trigonometrijskog reda

$$
w=\sum_{m=1}^{\infty} \sum_{n=1}^{\infty} c_{m n} \cdot \sin \frac{m \pi z}{a} \cdot \sin \frac{n \pi x}{b}
$$

čije su odgovarajuće derivacije:

$$
\left.\begin{array}{l}
\frac{\partial^{2} w}{\partial z^{2}}=\sum_{m=1}^{\infty} \sum_{n=1}^{\infty} c_{m n} \cdot\left(\frac{m \pi}{a}\right)^{2} \cdot \sin \frac{m \pi z}{a} \cdot \sin \frac{n \pi x}{b} \\
\nabla w=\sum_{m=1}^{\infty} \sum_{n=1}^{\infty} c_{m n}\left[\left(\frac{m \pi}{a}\right)^{2}+\left(\frac{n \pi}{b}\right)^{2}\right] \cdot \sin \frac{m \pi z}{a} \cdot \sin \frac{n \pi x}{b}
\end{array}\right\}
$$

Uvrštavanjem (6) u (5) dobivamo:

$$
c_{m n}\left\{\left[\left(\frac{m}{a}\right)^{2}+\left(\frac{n}{b}\right)^{2}\right]^{2}-\frac{\sigma \cdot h}{D} \cdot \frac{1}{\pi^{2}}\left(\frac{m}{a}\right)^{2}\right\}=0
$$

Jednadžba stabilnosti će biti za $c_{m n} \neq 0$ :

$$
\left[\left(\frac{m}{a}\right)^{2}+\left(\frac{n}{b}\right)^{2}\right]^{2}-\frac{\sigma_{c r} \cdot h}{D} \cdot \frac{1}{\pi^{2}}\left(\frac{m}{a}\right)^{2}=0
$$

Iz ovoga slijedi da je:

$$
\sigma_{c r}=\frac{\pi^{2} D}{b^{2}}\left[m \cdot \frac{b}{a}+\frac{n^{2}}{m} \cdot \frac{a}{b}\right]^{2}
$$


Ako uvedemo oznake:

$$
\begin{aligned}
& \alpha=\frac{a}{b} \\
& \sigma_{E}=\frac{\pi^{2} D}{b^{2} h}
\end{aligned}
$$

onda je kritično naprezanje $\sigma_{c r}$ izraženo preko Eulerovog naprezanja $\sigma_{E}$

$$
\sigma_{c r}=\sigma_{E}\left(\frac{m}{\alpha}+\alpha \frac{n^{2}}{m}\right)^{2}
$$

Ako izraz kojim množimo $\sigma_{E}$ označimo s $k_{m n}$, kritično naprezanje je

$$
\sigma_{c r}=k_{m n} \cdot \sigma_{E}
$$

Minimalno kritično naprezanje dobiva se iz uvjeta minimuma vrijednosti $k_{m n}$, uzimajući da je $n=1$ :

$$
\begin{aligned}
& \frac{\partial k_{m 1}}{\partial m}=0 \\
& \frac{\partial k_{m 1}}{\partial m}=2\left(\frac{m}{\alpha}+\alpha \frac{1}{m}\right)\left(\frac{1}{\alpha}-\alpha \frac{1}{m^{2}}\right)=0
\end{aligned}
$$

odakle je:

$$
\left(\frac{1}{\alpha}-\alpha \frac{1}{m^{2}}\right)=0
$$

te je:

$$
\begin{aligned}
& \alpha=m=2, \\
& k_{m 1}=\left(\frac{m}{\alpha}+\alpha \frac{1}{m}\right)^{2}=4
\end{aligned}
$$

Znači da je u ovom slučaju $(n=1)$ :

$\sigma_{c r}=k_{m n} \sigma_{E}=k_{\sigma} \sigma_{E}=4 \sigma_{E}$

Zavisnost $k_{m 1}$ i $\alpha$ može se prikazati za pojedine vrijednosti $m$ pomoću krivulja na slici 1.7: 


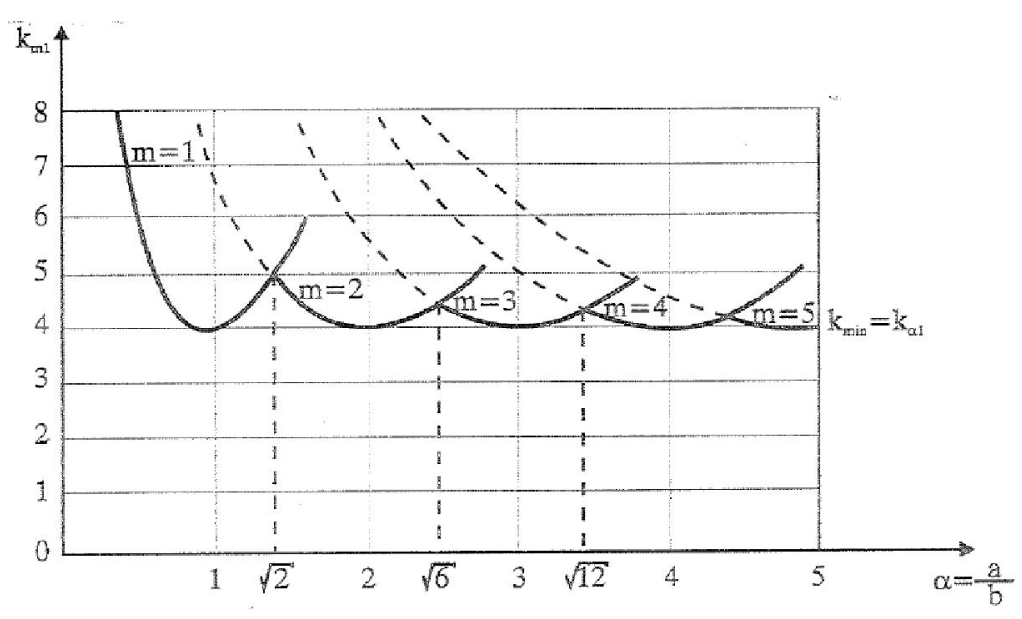

Slika 1.7 - Dijagram krivulja ovisnosti $k_{m l}$ i $\alpha$

Očigledno je da se najmanje kritično naprezanje dobiva kada je koeficijent $\alpha$ cijeli broj. Tako npr. za ploču s odnosom $\alpha=a / b=2$ i jednoosno tlačno ravnomjerno opterećenje dobiva se oblik izbočivanja koji se sastoji od dva poluvala, slika 1.8:

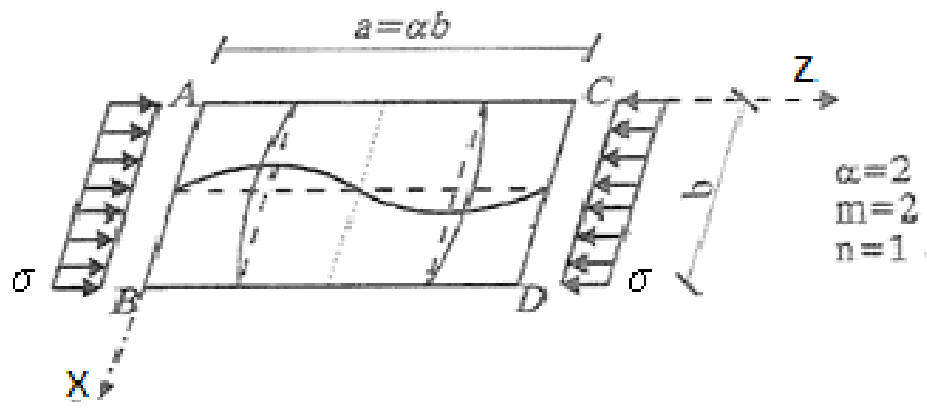

\section{Slika 1.8 - Oblik izbočavanja}

\subsection{Plošni elementi u tlaku prema EN 1993-1-1 i EN 1993-1-5}

Iz teorije plošnih nosača prikazane u prethodnom poglavlju 1.2., pokazano je da se elastično kritično naprezanje izbočivanja ploče izračunava iz sljedećeg izraza:

$$
\sigma_{c r}=\frac{k_{\sigma} \cdot \pi^{2} \cdot E}{12 \cdot\left(1-v^{2}\right)} \cdot\left(\frac{t}{b}\right)^{2}=k_{\sigma} \cdot \sigma_{E}
$$

U ovom izrazu je:

$k_{\sigma}$ - faktor (koeficijent) izbočivanja ploče uveden u EN 1993-1-1 [2] koji uzima u obzir uvjete oslanjanja, raspodjelu naprezanja u poprečnom presjeku (zbog čega je u indeksu simbol $\sigma$ ) i odnos dužine i širine ploče, slike 1.8 i 1.9.a

$\sigma_{E}$ - idealno naprezanje izbočivanja trake debljine $t$, širine $b$ i duljine $L$

$v \quad$ - Poissonov koeficijent

$E \quad$ - modul elastičnosti.

Otvoreni poprečni presjeci sastavljeni su od više plošnih elemenata koji su slobodni duž jednog uzdužnog ruba i u pravilu su vrlo dugački u odnosu na širinu, slika 1.9.b. Oblik izbočivanja takvog vanjskog elementa 
prikazan je na slici 1.9.c. Ovisnost odnosa dužine i širine elementa $L / b$ i faktora izbočivanja $k_{\sigma}$ za dugački tanki vanjski element slobodan po jednom rubu, prikazana je na slici 1.9.d iz koje se uočava da faktor izbočivanja $k_{\sigma}$ teži graničnoj vrijednosti $0,425 \mathrm{~s}$ povećanjem odnosa $L / b$. Faktor izbočivanja $k_{\sigma}$ zavisi od rubnih uvjeta i od odnosa dimenzija ploče.

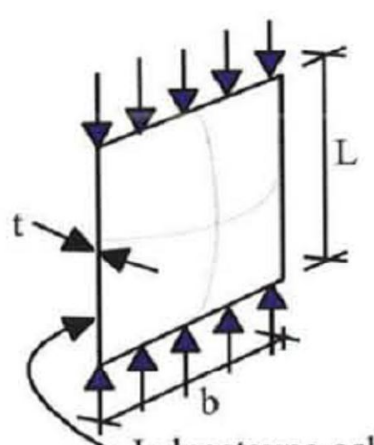

Jednostavno oslonjena na sva četiri ruba

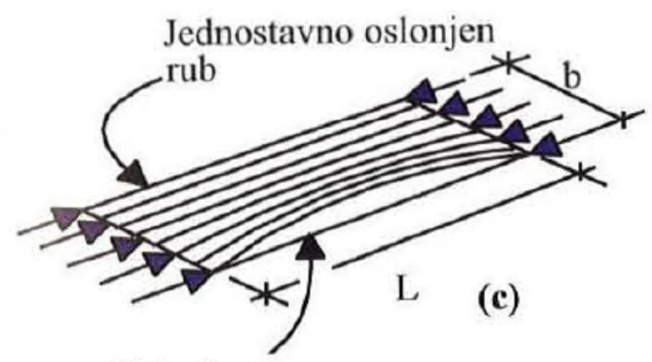

Slobodan rub

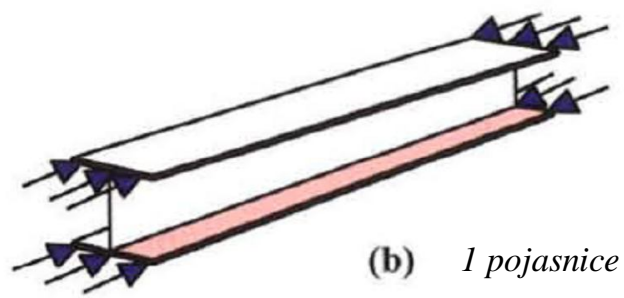

Koeficijent izbočavanja, $\mathrm{k}$

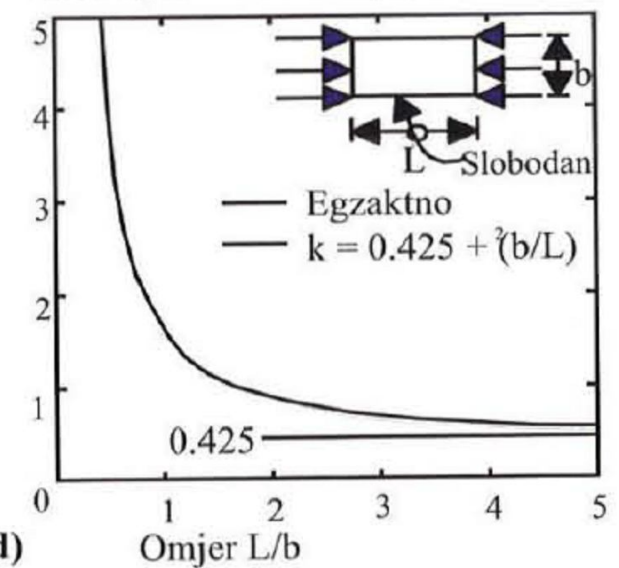

\section{Slika 1.9 - Ponašanje plošnih elemenata u tlaku}

Vrijednosti faktora izbočivanja $k_{\sigma}$ za nekoliko najčešćih oblika naprezanja na rubovima plošnih elemenata dane su u tablici 1.2. [1], i to za velike omjere L/b unutarnjih i vanjskih elemenata. Prvi korak kod određivanja faktora izbočivanja $k_{\sigma}$ je razmatranje rubnih uvjeta elementa, tj. utvrđivanje radi li se o unutarnjem ili vanjskom elementu u tlaku. $U$ drugom koraku uzima se u obzir raspodjela naprezanja po presjeku elementa preko omjera naprezanja u rubnim vlakancima $\psi=\sigma_{2} / \sigma_{1}$. Najuobičajeniji slučajevi su $\mathrm{s}$ elementom u tlaku $\mathrm{S}$ jednolikom raspodjelom naprezanja $\left(\sigma_{2}=\sigma_{1}\right)$, kada je $\psi=1$ i elementom izloženom savijanju s jednakim naprezanjima u rubnim vlakancima, ali suprotnih predznaka $\sigma_{2}=-\sigma_{1}$, kada je $\psi=-1$. 
Tablica 1.2 - Vrijednosti faktora izbočivanja $k_{\sigma}$ za nekoliko oblika raspodjele naprezanja na rubovima plošnih elemenata

\begin{tabular}{|c|c|c|c|c|c|}
\hline $\begin{array}{l}\sigma_{1} \\
\mathrm{I}\end{array}$ & $\sigma_{2}$ & $\begin{array}{c}\mathrm{I} \\
\sigma_{1,2}=\text { maksimalı }\end{array}$ & tlačno napre & $\sigma_{1}$ & $\sigma_{2}$ \\
\hline$\psi=\sigma_{2} / \sigma_{1}$ & +1 & $1>\psi>0$ & 0 & $0>\psi>1$ & -1 \\
\hline $\begin{array}{l}\text { Unutarnji } \\
\text { element }\end{array}$ & $k_{\sigma}=4,0$ & $k_{\sigma}=8,2 /(1,05+\psi)$ & $k_{\sigma}=7,81$ & $k_{\sigma}=7,81+6,29 \psi+9,78 \psi^{2}$ & $k_{\sigma}=23,9$ \\
\hline $\begin{array}{l}\text { Vanjski } \\
\text { element }\end{array}$ & $k_{\sigma}=0,43^{*}$ & $k_{\sigma}=0,57-0,21 \psi+0,07 \psi^{2}$ & $k_{\sigma}=0,57$ & $k_{\sigma}=0,57-0,21 \psi+0,07 \psi^{2}$ & $k_{\sigma}=0,85$ \\
\hline $\begin{array}{l}\text { Vanjski } \\
\text { element }\end{array}$ & $k_{\sigma}=0,43^{*}$ & $k_{\sigma}=0,578 /(\psi+0,34)$ & $k_{\sigma}=1,70$ & $k_{\sigma}=1,7-5 \psi+17,1 \psi^{2}$ & $k_{\sigma}=23,8$ \\
\hline
\end{tabular}

*približno dobiveno i na slikama 1.9d i 1.16

Na slikama 1.10 - 1.17 prikazani su dijagrami preuzeti iz literature [9] pomoću kojih se mogu odrediti približne vrijednosti faktora izbočivanja $k_{\sigma}$ za razne rubne uvjete i različite odnose $\mathrm{L} / \mathrm{b}$. Može se uočiti da dijagram na slici 1.9.d odgovara dijagramu na slici 1.16. Nadalje, za rubne uvjete i opterećenje kao na slici 1.6 dobivena je vrijednost faktora izbočivanja $k_{\sigma}=4,0$, a ista je vrijednost za unutarnji element poprečnog presjeka i $\psi=\sigma_{2} / \sigma_{1}=1$ dana u tablici 1.2 i prikazana na slici 1.14. Svi dijagrami na slikama 1.10 - 1.17 dani su samo za slučaj $\sigma=$ const. , te su dobiveni primjenom prethodno iznesene teorije tankih ploča. 


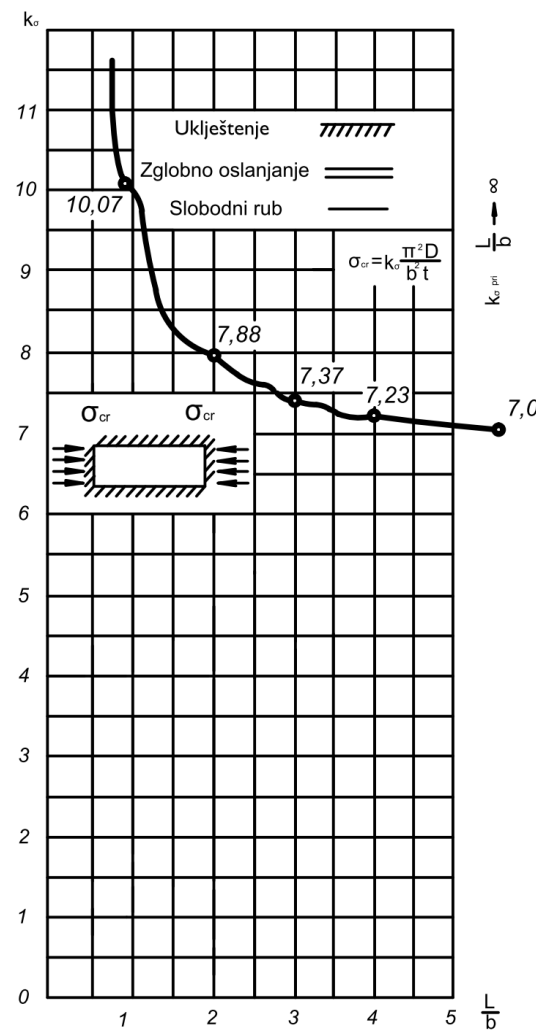

$\mathrm{L}$ - duljina elementa

b - širina elementa

Slika 1.10 - Vrijednosti faktora $k_{\sigma}$ za tlačno opterećen plošni nosač upet na svim krajevima

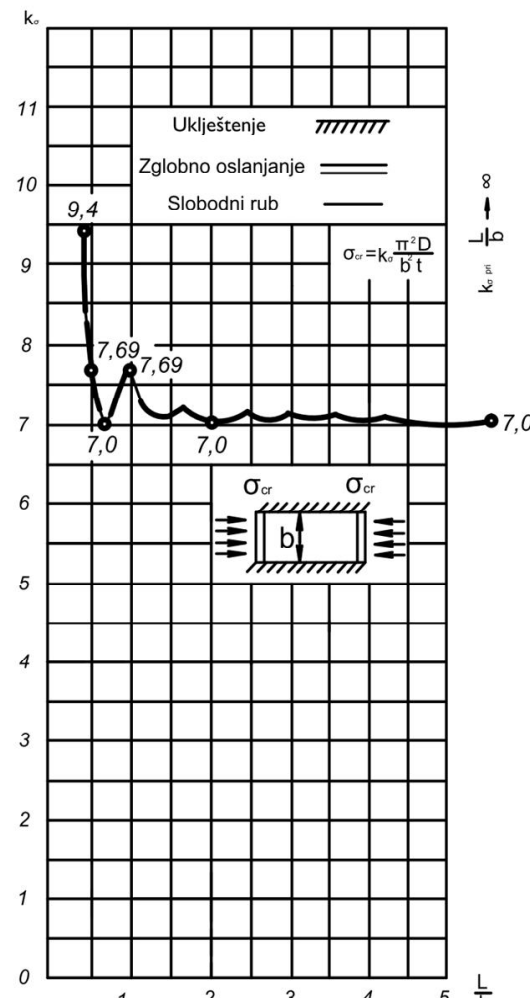

$\mathrm{L}$ - duljina elementa b - širina elementa

Slika 1.11 - Vrijednosti faktora $k_{\sigma}$ za tlačno opterećen plošni nosač s dvije strane upet, a s dvije slobodno oslonjen 


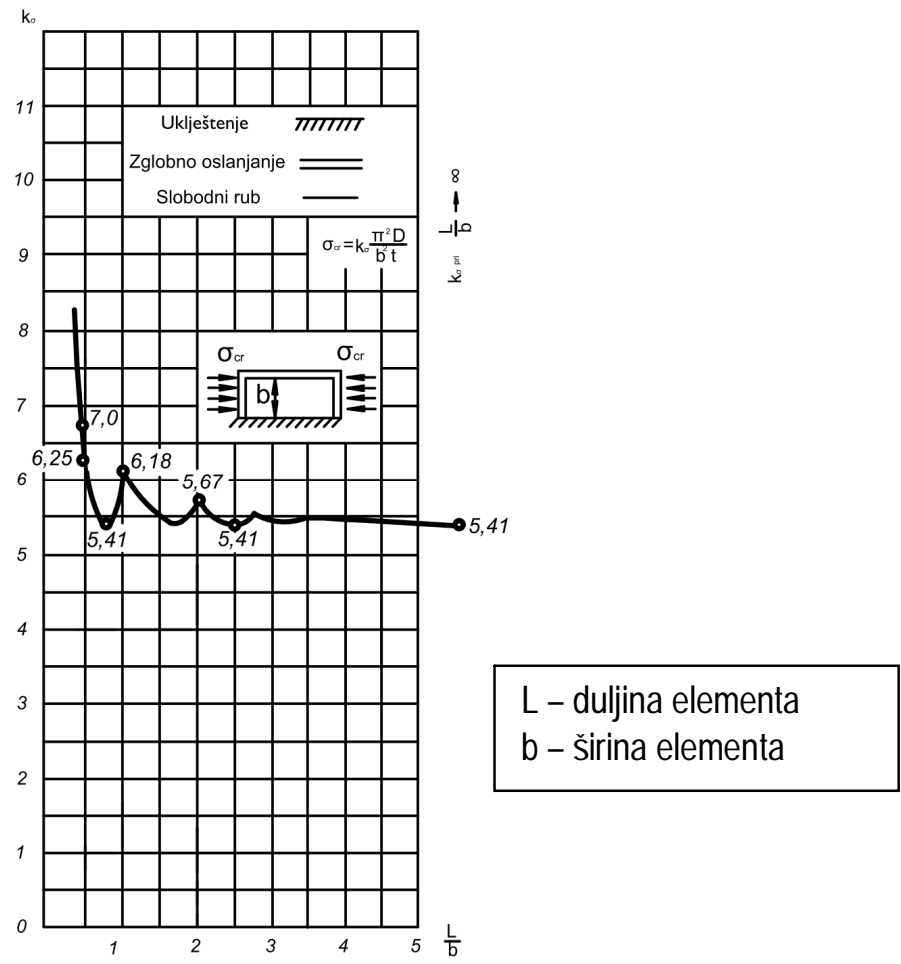

Slika 1.12 - Vrijednosti faktora $k_{\sigma}$ za tlačno opterećen plošni nosač s jedne strane upet, a s tri strane zglobno oslonjen

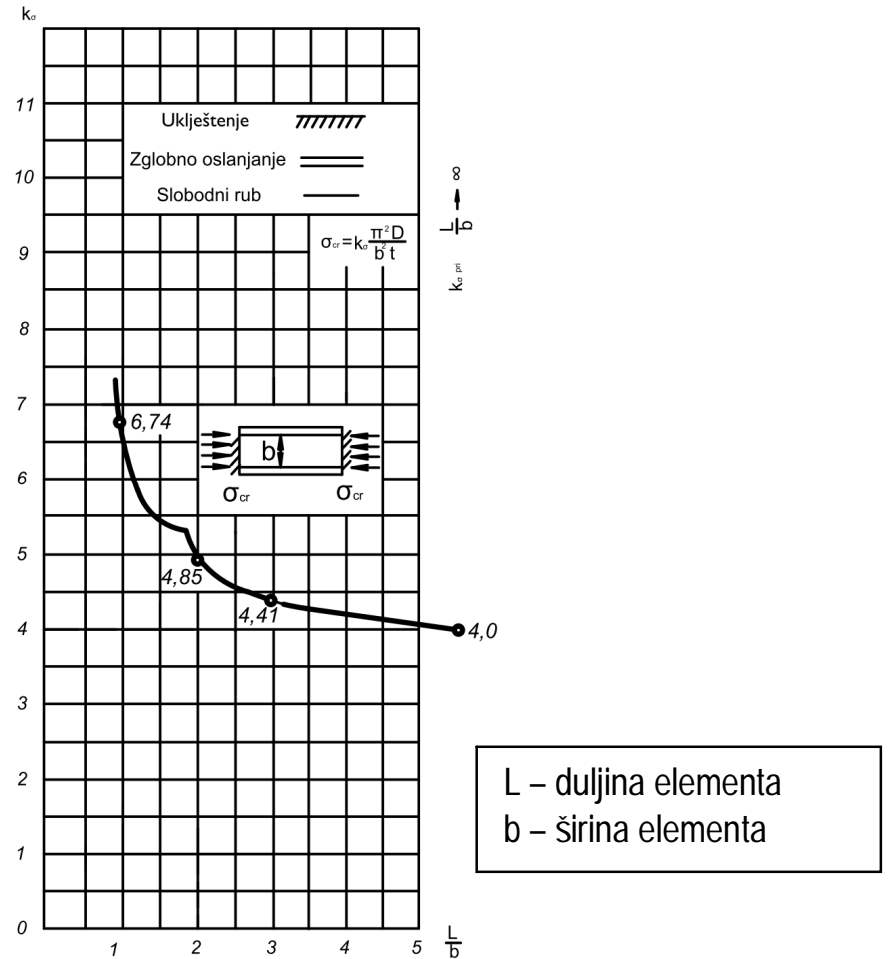

Slika 1.13 - Vrijednosti faktora $k_{\sigma}$ za tlačno opterećen plošni nosač s dvije strane upet, a s dvije strane zglobno oslonjen 


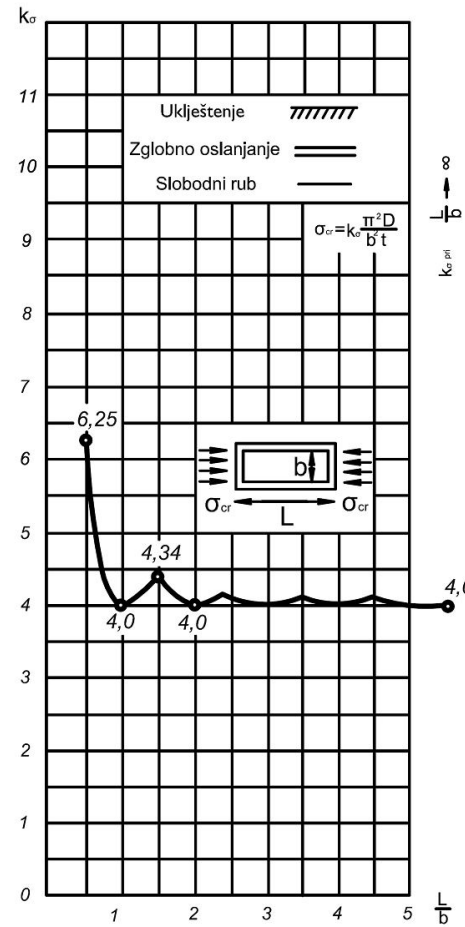

Slika 1.14 - Vrijednosti faktora $k_{\sigma}$ za tlačno opterećen plošni nosač sa svih strana zglobno oslonjen

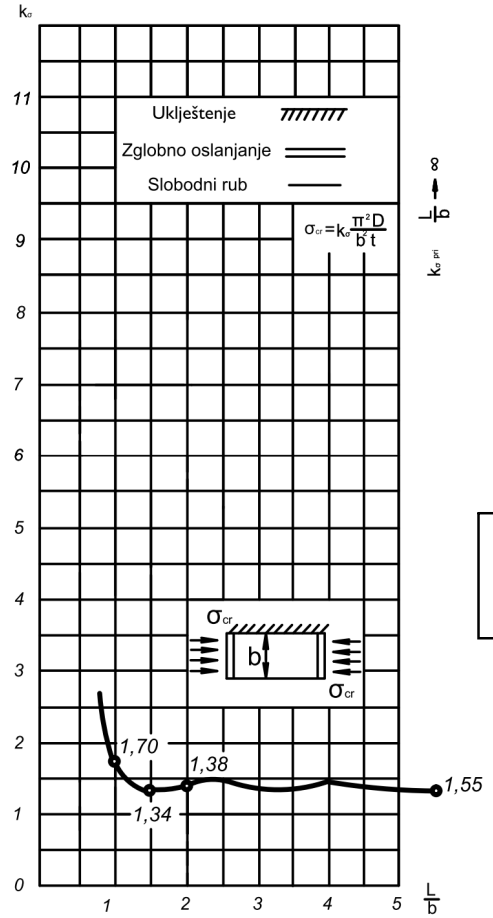

$L$ - duljina elementa

$b$ - širina elementa

Slika 1.15 - Vrijednosti faktora $k_{\sigma}$ za tlačno opterećen plošni nosač $\mathbf{s}$ dvije strane zglobno oslonjen, $\mathrm{s}$ jedne upet i s jedne strane slobodno oslonjen 


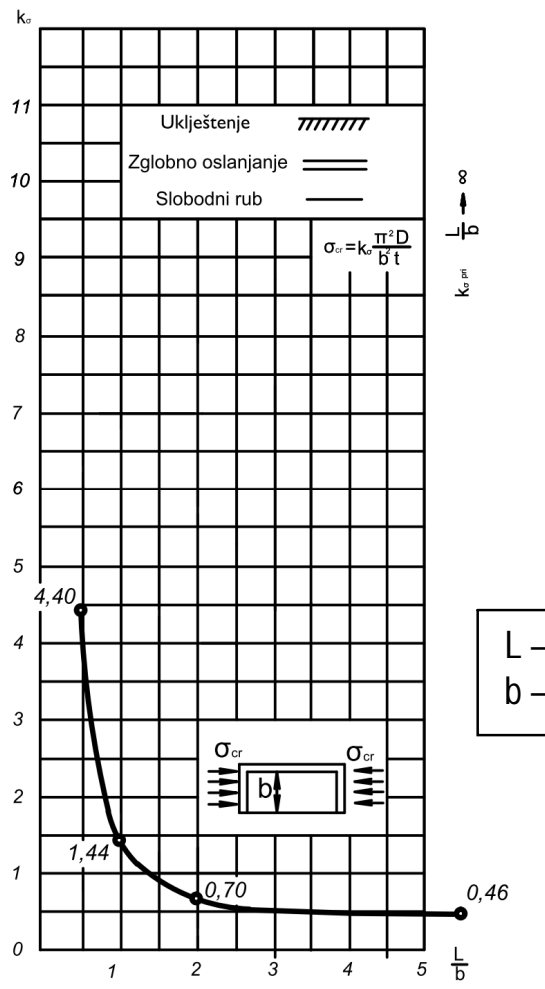

Slika 1.16 - Vrijednosti faktora $k_{\sigma}$ za tlačno opterećen plošni nosač s tri strane zglobno oslonjen i s jedne strane slobodno oslonjen

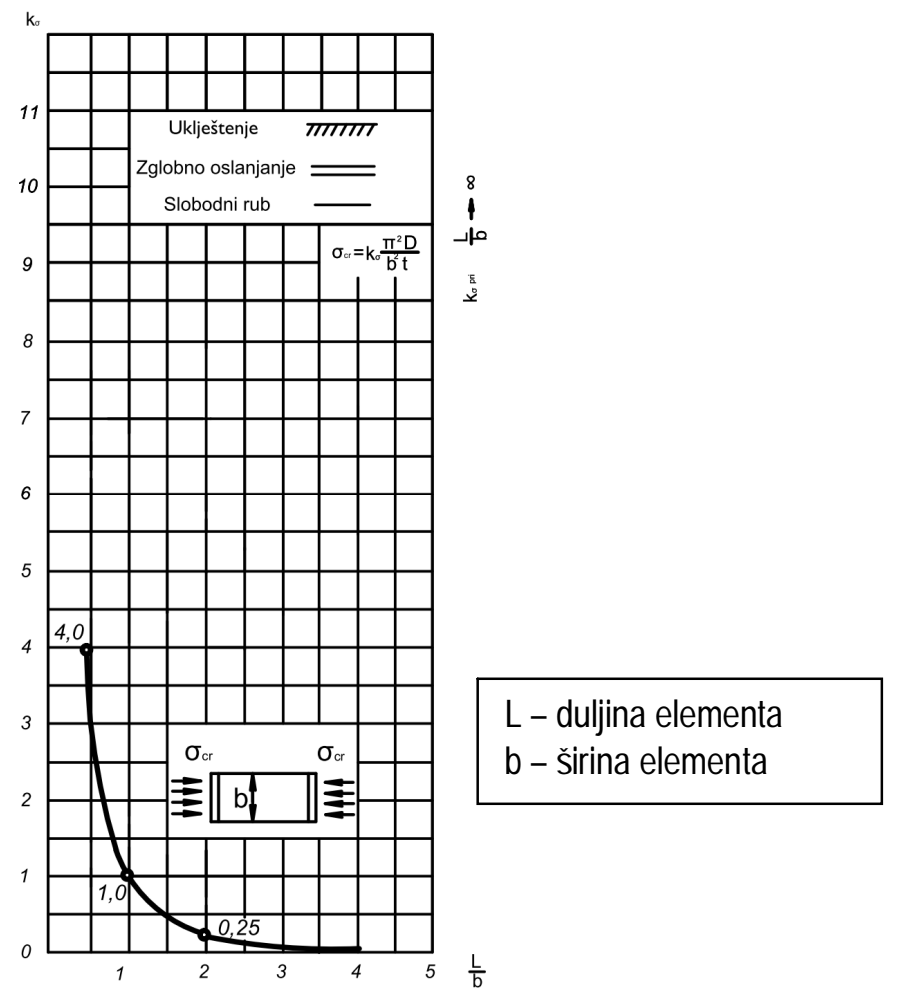

Slika 1.17 - Vrijednosti faktora $k_{\sigma}$ za tlačno opterećen plošni nosač $\mathbf{s}$ dvije strane zglobno oslonjen i s dvije strane slobodno oslonjen 


\section{Proračun plošnih nosača opterećenih u svojoj ravnini primjenom specijaliziranog softverskog paketa EBPlate Version 2.01}

Europski centar za normizaciju CEN prepoznao je važnost normizacije proračuna i dimenzioniranja tlačno opterećenih plošnih nosača te je uvedena posebna norma EN 1993-1-5 s nazivom PLATED STRUCTURAL ELEMENTS, za čiju primjenu su izrađeni posebni komentari i riješeni primjeri [10]. Budući da je primjena ove norme relativno zahtjevna, sačinjen je softver s nazivom EBPlate [11] za njenu lakšu uporabu koji se temelji na teoriji tankih ploča iznesenoj u prethodnom poglavlju. Softver određuje faktore izbočivanja i kritična naprezanja u vezi s elastičnim izbočivanjem plošnih nosača različitih rubnih uvjeta, opterećenih u svojoj ravnini. Karakteristike programa EBPlate, što su ulazni parametri te što se programom dobiva kao rezultat:

- $\quad$ program proračunava ploče nepromjenjive debljine (slika 2.1), izotropnih ili anizotropnih karakteristika;

- najprije treba zadati rubne uvjete ploče, a tri su moguća slučaja: zglobno oslonjen, upet rub ili elastično pridržanje definirano prema krutosti na savijanje i torzijskoj krutosti;

- definirati ojačanja uzdužno i poprečno, s istim i različitim karakteristikama (ortotropne ploče);

- provesti poseban tretman ojačanja sa zatvorenim poprečnim presjekom (npr. trapezni poprečni presjek);

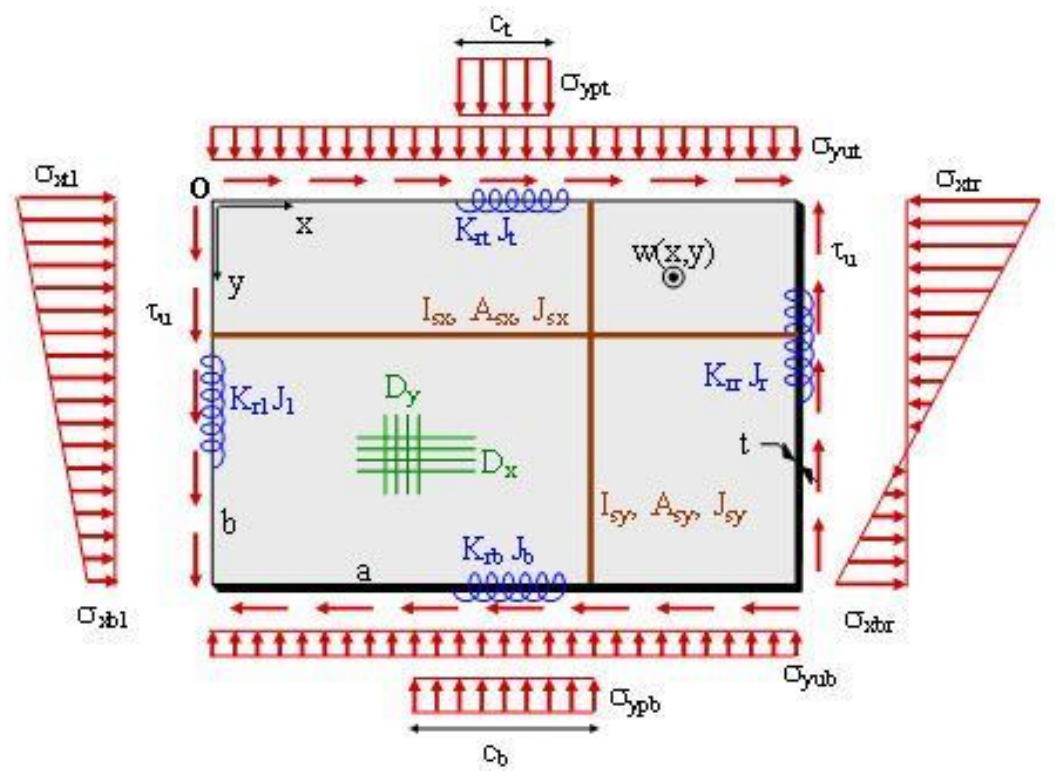

Slika 2.1 - Općeniti prikaz ulaznih podataka u programu EBPlate

- generirati raspodjelu naprezanja na način da se direktno definira naprezanje u elementu plošnog nosača;

- $\quad$ unijeti podatke raspodjele naprezanja iz nekog drugog softvera;

- izračunava minimalni kritični faktor $\phi_{c r}$ kojim se uvećavaju vanjska naprezanja na ploču da bi se postiglo njezino elastično izbočivanje; programom se nalaze svi oblici izbočivanja kojima su pridružene vrijednosti kritičnog faktora;

- trodimenzionalan prikaz oblika izvijenog modela;

- ispis liste rezultata dobivenih izračunom;

- eksportiranje matematičkih funkcija, izdvojena upotreba iz drugog programa itd. 
U nastavku je dan primjer izračuna faktora izbočivanja plošnog čeličnog elementa primjenom specijaliziranog softverskog paketa EBPlate. Najprije se zadaju dimenzije elementa, svojstva čelika i uvjeti oslanjanja. Element je slobodno oslonjen na sve četiri strane bez poprečnih i uzdužnih ukrućenja (slika 2.2).

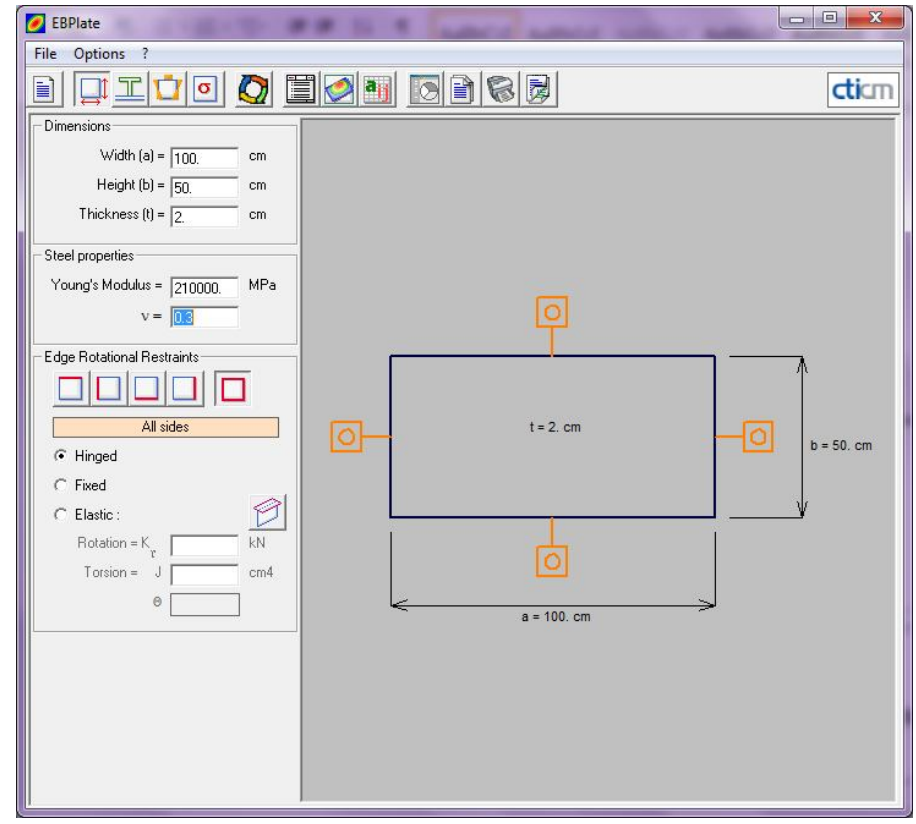

Slika 2.2 - Definiranje rubnih uvjeta

Kako bi se rezultat proračuna mogao usporediti s analitičkim rješenjem, na pravokutnu ploču je također primijenjeno jednoosno, tlačno ravnomjerno raspoređeno opterećenje (slika 2.3)

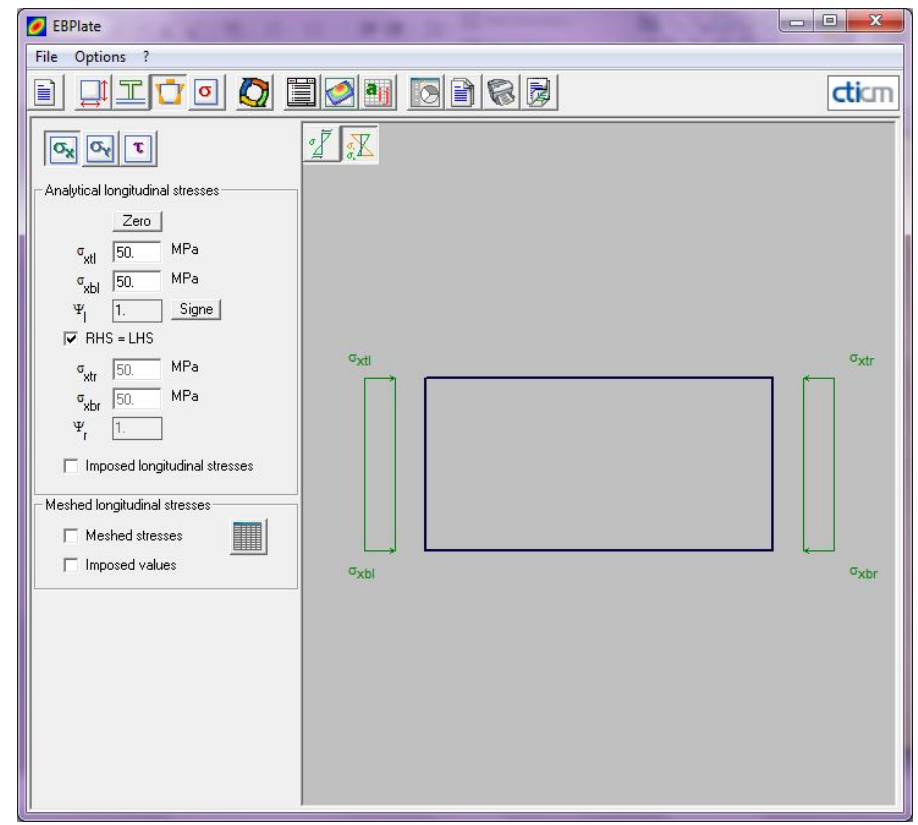

Slika 2.3 - Opterećenje na plošni element

Kritično naprezanje dano ovim softverom računano je pomoću teorije linearnog elastičnog izbočivanja idealiziranih plošnih nosača, tako da nema ograničavanja naprezanja kao kod realnih elemenata. Ove vrijednosti su općenito korištene za određivanje neodređenih parametara, kao na primjer reducirane vitkosti iz EN 1993-1-5: 
2006 čija je vrijednost potrebna za izračun otpornosti poprečnog presjeka. Dobiveni su faktori izbočivanja i kritična naprezanja. Vrijednost faktora izbočivanja iznosi 4,0 kao što je dobiveno analitičkim rješenjem istog primjera (slika 2.4).

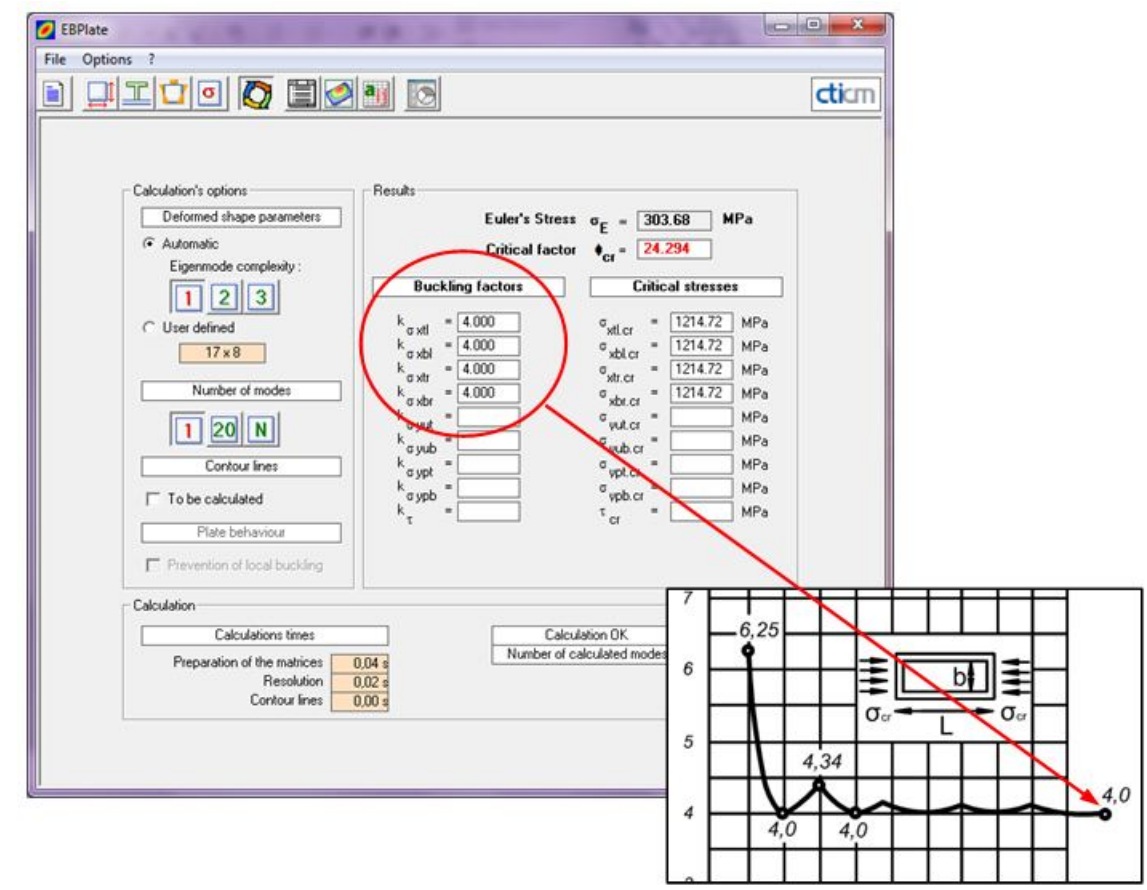

Slika 2.4 - Rezultati izračuna primjenom softvera

Izračunom je dobiven trodimenzionalan prikaz oblika izvijenog modela plošnog elementa. Izvijeni oblik ima dva vala u uzdužnom smjeru $(m=2)$ i jedan val u poprečnom smjeru $(n=1)$ (slika 2.5).

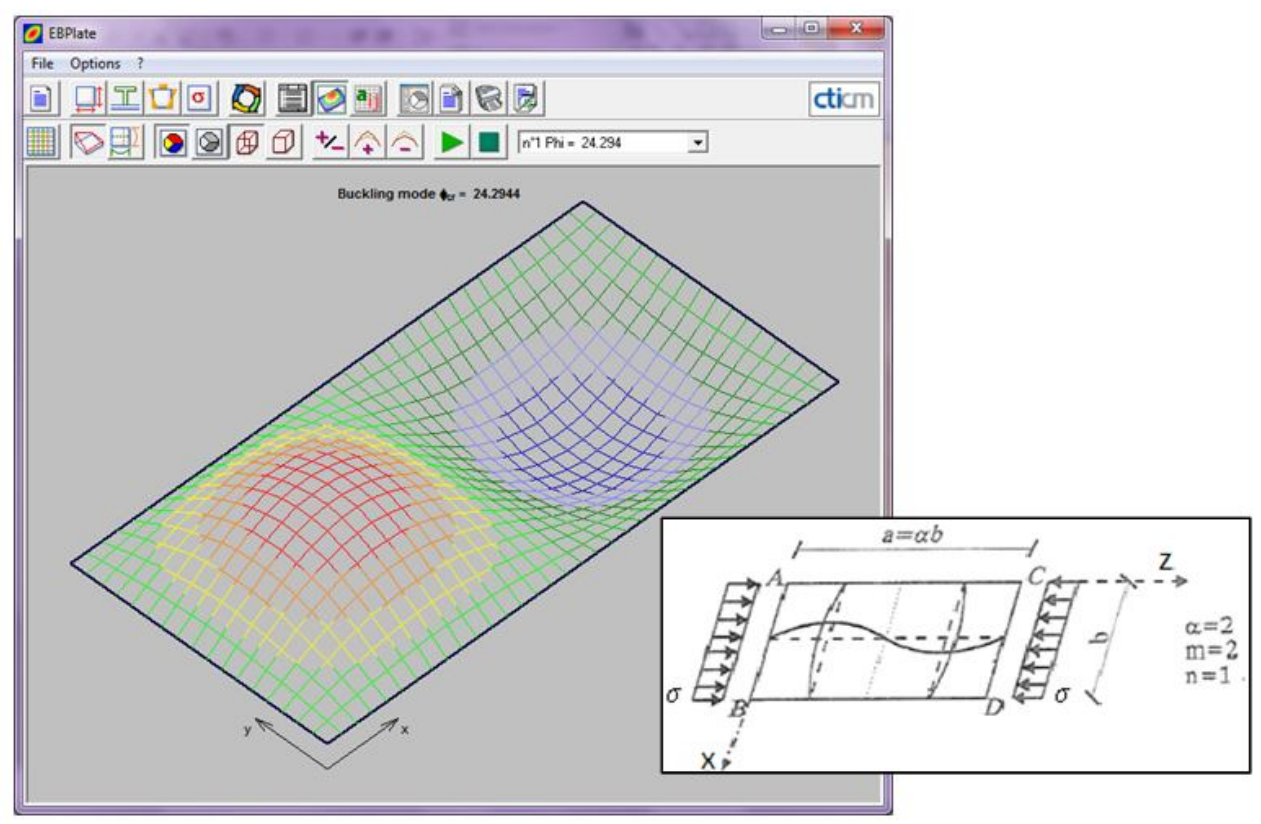

Slika 2.5 - Oblik izbočivanja dobiven primjenom softvera 


\section{Zaključak}

Za sve važne pojmove koji proizlaze iz teorije elastičnosti i teorije plastičnosti, a koji su uvedeni u konstrukcijske euronorme, trebalo bi posebnim objašnjenjima pokazati kako su ti pojmovi izvorno nastali. Jedno takvo objašnjenje kojim se pokazuje način na koji se dobije vrijednost kritičnog momenta bočno torzijskog izvijanja štapa, dan je u [6]. U ovom radu je primjenom opće teorije plošnih nosača pokazano kako su nastale vrijednosti faktora izbočivanja. Primjenom dobivene jednadžbe izbočivanja ploče na najjednostavnijem slučaju izbočivanja zglobno oslonjene pravokutne ploče na koju djeluje jednoosno, tlačno ravnomjerno raspoređeno opterećenje, analitički je dobiven faktor izbočivanja $k_{\sigma}=4,0$. Ista vrijednost faktora izbočivanja $k_{\sigma}$ može se dobiti iz dijagrama preuzetih iz literature [9]. Primjenom specijaliziranog softverskog paketa proveden je izračun plošnog elementa s istim uvjetima oslanjanja i istim opterećenjem te su dobiveni rezultati koji odgovaraju analitičkom rješenju. Primjenom navedenog softvera može se dobiti vrijednost faktora izbočivanja za proizvoljne rubne uvjete i opterećenje, bez ili s ukrutama na plošnom nosaču, pri čemu tako dobivene vrijednosti odgovaraju onima iz tablice 1.1. te ispunjavaju uvjete dane u europskim normama [3].

\section{Literatura}

[1] Androić, B., Dujmović, D., Džeba, I.: Čelične konstrukcije 1, IA projektiranje, Zagreb, 2009.

[2] Eurocode 3 - Design of steel structures - Part 1-1: General rules and rules for buildings, EN 1993-1-1:2005 E, CEN - European Comitee for Standardization, 2005.

[3] Eurocode 3 - Design of steel structures - Part 1-5: Plated structural elements, EN 1993-1-5:2006 E, CEN European Comitee for Standardization, 2006.

[4] Čaušević, M.: Statika i stabilnost konstrukcija, Školska knjiga, Zagreb, 2003.

[5] Kisin, S.: Stabilnost metalnih konstrukcija, Građevinska knjiga, Beograd, 2001.

[6] Markulak, D.: Proračun čeličnih konstrukcija prema EN 1993-1-1, Građevinski fakultet Sveučilišta Josip Juraj Strossmayer u Osijeku, Osijek, 2008.

[7] Markulak, D.: Posebna poglavlja čeličnih konstrukcija, Građevinski fakultet Sveučilišta Josipa Jurja Strossmayera u Osijeku, Osijek, 2010.

[8] Timoshenko, S., Gere, J.: Theory of Elastic Stability, McGraw-Hill, 1961.

[9] Umanski, A.: Konstrukterski priručnik (izabrana poglavlja), Građevinska knjiga, Beograd, 1980.

[10] Johansson, B., Maquoi, R., Sedlacek, G., Müller, C., Beg, D.: Commentary and Worked Examples to EN 1993-1-5 „Plated Structural Elements“, CEN - European Comitee for Standardization, 2007.

[11] Kompjutorski softver: EBPlate Version 2.01, 2007. (www.cticm.com) 